\title{
Space: A useless category for historical analysis?
}

DOI:

10.1111/hith.10676

\section{Document Version}

Submitted manuscript

Link to publication record in Manchester Research Explorer

\section{Citation for published version (APA):}

Jerram, L. (2013). Space: A useless category for historical analysis? History and Theory, 52(3), 400-419. https://doi.org/10.1111/hith.10676

\section{Published in:}

History and Theory

\section{Citing this paper}

Please note that where the full-text provided on Manchester Research Explorer is the Author Accepted Manuscript or Proof version this may differ from the final Published version. If citing, it is advised that you check and use the publisher's definitive version.

\section{General rights}

Copyright and moral rights for the publications made accessible in the Research Explorer are retained by the authors and/or other copyright owners and it is a condition of accessing publications that users recognise and abide by the legal requirements associated with these rights.

\section{Takedown policy}

If you believe that this document breaches copyright please refer to the University of Manchester's Takedown Procedures [http://man.ac.uk/04Y6Bo] or contact uml.scholarlycommunications@manchester.ac.uk providing relevant details, so we can investigate your claim.

\section{OPEN ACCESS}


Forum: At Home and in the Workplace: Domestic and Occupational Space in Western Europe from the Middle Ages

6.

SPACE: A USELESS CATEGORY FOR HISTORICAL ANALYSIS?

\author{
LEIF JERRAM ${ }^{1}$
}

\begin{abstract}
Much fuss has been made of the "spatial turn" in recent years, across a range of disciplines. It is hard to know if the attention has been warranted. A confusion of terms has been used-such as space, place, spatiality, location - and each has signified a cluster of often contradictory and confusing meanings. This phenomenon is common to a range of disciplines in the humanities. This means, first, that it is not always easy to recognize what (if anything) is being discussed under the rubric of space, and second, that over-extended uses of the cultural turn have stymied meaningful engagement with (or even a language of) materiality in discussions of space. This article shows how materiality has been marginalized both by a casual vocabulary and a vigorous a priori epistemological holism on the part of scholars, and how the spatial turn has been too closely linked to the cultural turn to allow it to develop its fullest explanatory potential. It demonstrates how historians might profitably theorize the significance of place and space in their work (borrowing techniques from geographers and anthropologists, and referring to the phenomenological tradition), and sets out some challenges for using space more effectively in explanatory systems. Inspired by environmental history, sociology, and science and technology studies, I propose a way of establishing space as different from conventional historical handling of materiality, and end by identifying some methodological problems that need to be solved if we are to proceed on a surer footing.
\end{abstract}

Keywords: space, place, location, phenomenology, materiality, buildings, history, environment

It is a commonplace to assert, across a range of disciplines, that there has been a "spatial turn" in the humanities in the last few years. There has been enormous attention to the "spatial," but I will argue in this article that this attention has, in part, functioned to cover up a profound silence about space and has over-relied on under-theorized notions of place. I will suggest that the "spatial turn" is an extension of the cultural turn and does little to help us engage with the matter and substance of human experience. I do this not as a curmudgeon keen to return to the "common-sense" values of "proper" empirical history, someone who may be hostile to the many reflexive turns that historians have taken over the last thirty or so years. Quite the reverse. I have argued consistently throughout my work that space is a primary category through which the human experience needs to be analyzed and explained. ${ }^{2}$ I have focused particularly on those spaces that are

1. The author particularly thanks Stephen Mossman, Nick Stargardt, Moritz Foellmer, and the very helpful referees for help in preparing this article.

2. See, in particular, Leif Jerram, Streetlife: The Untold Story of Europe's Twentieth Century (Oxford: Oxford University Press, 2011); Germany's Other Modernity: Munich and the Building of 
conditioned by the built environment. But there is a fundamental problem: very few scholars in any discipline (myself included) have explained precisely what space is, and when they have, it is often treated as a dimension of the human imaginary. This limits clarity about what is being analyzed, and stalls discussion of materiality in its tracks.

In our everyday lives, we intuit the importance of physical space in all sorts of ways, and we can often produce examples of its impact on our own lives. For example, those who grew up sharing a bedroom with siblings often talk of the different forms of sociability and experiences of adolescence they had compared to those who had their own room. Few university academics are indifferent to the space in which they work: how much natural light it has, the quantity of surface area it includes, whether they share it or not, its proximity to or distance from others in the same discipline, or from the parking lot or the photocopier. This intuition is powerful in us and persuades us that space influences our own lives, such that we invest considerable emotional and financial resources to make them "just so." I feel confident enough to assert that no reader of this article is indifferent to where he or she is.

For example, it is easy to intuit but fiendishly hard to demonstrate that family life and therefore issues of sexuality, leisure, gender, age, and generation are altered by the availability of dwelling space in the first instance, and by internal spatial disposition in the second. As Greta Bucher has shown, the disposition of solids, voids, and people in postwar Moscow was central to increasing or lowering the stresses and tensions for families, and might maintain or break a family unit in a society under duress. ${ }^{3}$ For example, Elena lived in a room with four other family members, in an apartment they shared with three other families. She adapted her behavior on her wedding night to fit this spatial situation: "We stood [on our bed] in the corner and he hung a curtain around the other two sides. We didn't kiss, we couldn't make any noise, because, you understand, that in the same room were my mother and her brother." ${ }^{4}$ Elena then went on to elaborate how this lack of space and disposition of things relative to people destroyed her and her husband's psychosocial well-being. If we agree with Elena's conclusions about the interplay of physical space and family life, we should be able to identify a method to verify them; if, however, we dismiss Elena's conclusions (after all, plenty of rich people in big houses end their marriages too), we should be honest and be able to say that we disagree with Elena's analysis of her own life, and why.

It seems clear that the space was doing something here (or that Elena thought it was). And one might extend this argument. In an article on social housing in the Weimar Republic, I tried to show that material space was a significant tool to enable the state to interact with its citizens: to shape citizens' behavior in a way that they could not avoid. ${ }^{5}$ My contention was (and still is) that when human sub-

Metropolis (Manchester, UK: Manchester University Press, 2007); Jerram, "Kitchen Sink Dramas: Women, Modernity and Space in Weimar Germany," Cultural Geographies 13 (2006), 538-556.

3. Greta Bucher, Women, the Bureaucracy and Daily Life in Post-war Moscow, 1945-1953 (New York: Columbia University Press, 2006), 25-38, 107-136; Jerram, Streetlife, 336-339.

4. Bucher, Women, the Bureaucracy and Daily Life, 118.

5. Jerram, "Kitchen Sink Dramas." 
jects aim to intervene in each others' lives, it is hard for them to make the intervention both unavoidable and stable, without persistent reinvestment of resources. Education systems and police forces, for example, require constant reproduction every single day - and even with that investment, many citizens of modern states ignore or challenge their interventions, in both open and undiscovered ways. But no-one can exist outside the space they are in. Space, as I will define it in this article (and as I have conceived of it in more recent work on European history), offers a way of understanding relationships that opens up the particular and the peculiar, but while offering tools to link the particular to wider processes that tend to be analyzed in taxonomic categories like class, race, gender, sexuality, state, expertise, or law. Space is (literally, not at all figuratively) how these taxonomic categories come into relationship with one another. As Engels argued in The Condition of the Working Class in England, in the great towns of the North, such as Manchester, Leeds, and Glasgow, space was not incidental to the production and maintenance of a grotesquely unequal system; space was precisely the mechanism that generated and sustained that system. ${ }^{6}$ The rich man in his castle and the poor man at his gate cannot have a "real" relationship understood only in theoretical terms; relying on a classification of their relationship through the tropes of class or capitalism perpetually confines explanation to the abstract realm of the academic construct. It privileges the academic standpoint, and not the (literal and metaphorical) standpoint of the subjects we claim to understand.

Yet if we accept that spaces intervene, it is also unclear whether any resultant change in human actions is dependent on other, more important factors (for example, beliefs about the nature of sex or gender roles), and that are in part materially driven. Engels did not think so, but potentially, the role of the space itself is a mere curiosity - a tautology, embellishing processes originating elsewhere, but not productive of them. As one influential urban sociologist, profoundly alert to the historical production of the phenomena he seeks to explain, reminds us: "To forget that urban space is a historical and political construction in the strong sense of the term is to risk (mis)taking for 'neighborhood effects' what is nothing more than the spatial retranslation of economic and social differences."7 Loïc Wacquant here proposes that the spatial arrangement of things and people may be the product of more important processes that we should be studying, rather than causes of them. ${ }^{8}$ (Although how such processes could take effect extra-spatially is a fraught question; it would be like studying the impact or actions of the automobile without any reference to gasoline or oil.)

This essay seeks to ask some questions about space-but not necessarily answer them. I am seeking to define a problem, not to solve it. I will do this by reflecting on several problems in the field. The first section identifies a widespread confusion in the humanities about what space is-about what is being

6. Friedrich Engels, The Condition of the Working Class in England in 1844 (London: Allen and Unwin, 1944), 23-74.

7. Loïc Wacquant, Urban Outcasts: A Comparative Sociology of Advanced Marginality (Cambridge, UK: Polity, 2008), 9.

8. This is a well-established view. See, for example, the work of David Harvey on Paris - most recently, Paris: Capital of Modernity (London: Routledge, 2005). 
referred to with the word. The goal of this first section is to crystallize a set of confusions or contradictions and offer a vocabulary to reinforce that crystallization. Even if the terminology suggested here is roundly rejected, it will bring the problem to consciousness and serve as a clarifying heuristic device. The second section reflects on how well developed ideas of place and location are in current scholarship - as opposed to space-but how rarely historians engage consciously with these. It highlights some of the values of "platial" (to coin an ugly neologism, but one that underlines the problems of using a word like "space" and "spatial" to refer to so many things) and "locational" approaches by stressing how a phenomenological heritage might assist historians in developing their analyses. The third section explores some suggestions about how to overcome these problems, and proposes some starting points for further work, by suggesting that we ditch a problematic a priori holism that pervades a range of disciplines in the humanities (geography, social theory, anthropology, history), and explore some of the possibilities inherent in science and technology studies and a sort of "naïve materialism" and "imaginative phenomenology."

\section{A CONFUSION OF TERMS}

If we are going to talk about a "spatial turn" in history, then we need to understand the fulcrum about which we are turning. That means defining what space is. A significant problem is that in academic usage, place and space can both refer to many things that often overlap, with the net result that one cannot really be sure what a scholar is talking about. For example, in Gerd Schwerhoff's comment on this forum, ${ }^{9}$ just running through Lefebvre, Simmel, Luhmann, and Schlögel produces thirteen possible "space" meanings or qualities, such that, following them, it is hard to know for sure what would not be space-given that they encompass actions, representation, communication, the thing that produces meaning, distance, virtuality, materiality. At the heart of the confusion are the words "place" and "space," which so often jumble up materiality, distributions, relationships, and meanings in very unhelpful ways. Although the two words are often used interchangeably, they both are often used to refer, in fact, to two or more of three distinct things, which may all be mutually constitutive, but which are all conceivable as being characterized by different qualities and effective in three different ways:

1. The proximate physical disposition of things in relation to one another and to humans - such as walls, streets, motorways, telephones, air-vents, mountains. This is space as meant in the following sentence: "the lack of space meant four families had to share the same apartment, and four people had to live in the same room."

2. The location of things on the earth's surface, and the relationship between those locations and the scale/density/complexity/distribution of those relationships. This models places as locations, and space as a universal 
or infinite (but meaningless) plane on which locations are situated. This is the sense of space as most geographers mean it: spacing, where space is a meaningless vector throughout which things (meanings, items, practices) are distributed. ${ }^{10}$

3. The values, beliefs, codes, and practices that surround a particular location, whether that location is real or imagined-for example: the ways that sleeping arrangements are organized differently in varying cultures; or visions of heaven in different religions; or the ways the Cenotaph in London comes to carry meanings of mourning, nation, monarchy; or the ways kitchens are characterized as a "woman's place."11

I propose that we use the word "space" to refer to 1: the particular proximate disposition of things in relation to one another, and to humans; that we use positional words like "site," "location," "distance," "area," and "distribution" to refer to 2 ; and that we use the word "place" to refer to 3. To sum up: space is material, location is relational or positional, place is meaningful. If we do this, we will see the very rich and fruitful (albeit under-theorized) use of "place" and location in historical scholarship, but the somewhat impoverished (or at least, confusing) use of the word "space" in most scholarship, my own included. This should stimulate us to think through space more thoroughly, if we are still convinced that it matters, or to ditch the "spatial turn" (and think through that) if we are not.

The idea, though, that "space" can have a meaning in the sense we often use it is not helpful to effective spatial analysis. We talk of gay space, male space, sacred space, and so on; but a space cannot possess the quality of being gay, male, or sacred. A sports hall that is used for Pentecostal meetings on a Sunday afternoon may shift from being a "male space" to a "sacred space," but the space may well be the same, and neither would help you calculate the cost of re-laying the floor, such would be their a-spatiality. It is a crass anthropomorphism to give space these (or any other human) qualities - and one that once again serves to marginalize the material. Far too often, knowledge generated from humans (in this case, about the gender of people playing basketball, say, and the religious beliefs of a confessional group) is read into or onto a space from knowledge generated elsewhere, and then read back off the space as if that were the source of the knowledge, and then fêted as a new evidential category. Such a practice does not seem to warrant a "turn."

This elision is reasonably common in historians' treatment of space. Consider Thomas Rohkrämer and Felix Schulze's recent reflection on space and place. Their model emphasizes that place is about experience, meaning, and perception. So far, so platial (in my definition of the term). However, when clarifying what

10. See, for example, Eric Sheppard, "The Spaces and Times of Globalization: Place, Scale, Networks and Positionality," Economic Geography 3 (2002), 307-330; Doreen Massey, “A Global Sense of Place," in Reading Human Geography, ed. T. Barnes and D. Gregory (London: Arnold, 1997), 315-323; Massey, For Space (London: Sage, 2005), 81-143; Nigel Thrift, "From Born to Made: Technology, Biology and Space," Transactions of the Institute of British Geographers 30 (2005), 463-476; Jonathan Murdoch, Post-Structuralist Geography: A Guide to Relational Space (London: Sage, 2006).

11. This tripartite division resembles that in Thomas Gieryn, "A Space for Place in Sociology," Annual Review of Sociology 26 (2000), 463-496, but adapts the definitions offered there. 
space is, they continue: "'Space' is used to denote an abstract, distant perspective, for example a scientific analysis, a bird's eye view, or a modern map reducing space to a manageable, two-dimensional relationship which can give the sense (or illusion) of control."12 So space is a perspective, like a map, not the thing upon which one has the perspective, whereas they conclude that place is "a multiplicity of heterogeneous influences and forces, relations, negotiations, practices of engagement, power in all its forms." ${ }^{13}$ And they also argue, using space and place almost terminologically interchangeably, that: "Human understandings of and relationships to space are to a large degree socially constructed, but natural and humanly constructed places also have power over humans (without, of course, determining their actions)." 14

So in this analysis, the words "space" and "place" seem relatively interchangeable, and the word "space" does not denote the thing itself, but a) a perspective on it, or b) a system for representing it, like a map. A map is, argues Edward Dimendberg, another variety of metaphor analogous to language, so following Dimendberg, Rohkrämer, and Schulz, place is a variety of meaning, and space is a sort of language - and language is a variety of meaning..$^{15}$ Meanings, meanings, everywhere. Indeed, in this issue, Willem de Blécourt defines space in a similarly immaterial way, arguing that, "[i]n a sense, it [space] does not exist outside the way it is perceived." ${ }^{16}$ Following spatial definitions like these denies a language or terminology of materiality from even entering into scholarly analysis, let alone being credibly theorized.

\section{Place and Location, Space and the Void: Ambiguous Meanings}

The situation with the word "place" is marginally better, though there are some confusing linguistic overlaps to bring to consciousness here too. First, place sometimes refers to location (what Schwerhoff in this issue calls "concrete place" ${ }^{17}$ ), but sometimes it refers to something quite different-the qualities, practices, beliefs, representations, and symbols that cluster at that location. Second, space sometimes refers not to the disposition of things in relation to one another and to people at a particular location, but sometimes is taken to signify a meaningless void for arranging and sorting the relationships among locations. So for Pierre Nora, places (lieux) are both specifically geographical, marking defined locations on the surface of the globe (like the tomb of the unknown warrior under the Arc de Triomphe), and also about meanings and symbols and experiences that may cluster there..$^{18}$ So in Nora's analysis, "lieu" refers both to location and

12. Thomas Rohkrämer and Felix Schulz, "Space, Place and Identities," History Compass 5 (2009), 1340.

13. Ibid., 1341.

14. Ibid., 1345.

15. Edward Dimendberg, "The Limits to Emplacement: A Reply to Philip Ethington," Rethinking History 4 (2007), 513-516.

16. Willem de Blécourt, “'Keep That Woman Out!' Notions of Space in Twentieth-Century Flemish Witchcraft Discourse," History and Theory 52, no. 3 (2013), 363.

17. Schwerhoff, "Spaces, Places, and the Historians," 425, 428.

18. Pierre Nora, "Between Memory and History: Les Lieux de Mémoire," Representations 26 (1989), 7-24; Les Lieux de mémoire (Paris: Gallimard, 1984), and the vast scholarship on memory that that has stimulated, such as Etienne François and Hagen Schulze, Deutsche Erinnerungsorte, 3 vols. 
place as I have defined them: sites with specific geo-coordinates (location), and complex sociocultural systems of managing human experience associated with those sites (place). So once again, it is impossible to know with our current chaotic vocabulary if scholars are addressing locations ("concrete places") or the cultures, practices, values, and symbols that cluster there. Krisztina Robert, in this issue, implicitly recognizes this duality, stressing that actions redefine the meanings of locations; they are platially transformative. ${ }^{19}$ When she wishes to distinguish between "home" and "front" (two locations), she shows clearly that it is the performances at each that give them their meanings. Places, crucially, need not have a geographical location at all-like heaven, or Hogwarts, or "olde England." (Whether a space can be imaginary is a more fraught question altogether, and one that this essay does not have room to address. In Arthur Koestler's Darkness at Noon, Rubashov sits in a cell. Rubashov is a fiction; the cell is a fiction. But Rubashov relates to the cell as if it were real. Whether the cell should be approached as a place or a space is a question to set to one side for now.)

The confusion around place extends to space. For many geographers, space is a characterless vector throughout which places (confusingly, both locations and meaning/performances associated with them) are dispersed. For example, Tim Cresswell states that, "Places have space between them," implying here that "place" is like a point on a map (as well as being a cluster of meanings, which he argues vigorously as well), and that space is a void between things - so is therefore the thing that constitutes "distance." ${ }^{20}$ The idea of space as a universal plane, an aggregated interplay of locations is not useless-but we should be clearer about what it is. Paul Gilroy uses it to good effect, for example, in The Black Atlantic. In this work, the Atlantic functions not so much as a material thing that conditions the behavior of the other things or people that are proximate to it (the Atlantic does not "make" black identity happen), but as a code for a totality of the plane of the interplay of locations, behaviors, conventions, and cultures. ${ }^{21}$ Jürgen Habermas's model of the "public sphere" would also be an example of the potency of modeling the world as a set of interconnected points (in this case, ports, coffeehouses, trading houses, newspaper presses, courts in the eighteenth century) in which the nature of each point as a physical entity is less significant than the product of the aggregate interrelationship among them. ${ }^{22}$ Thus, for Gilroy, the Atlantic is an area or network, not a specific space, and for Habermas the public sphere is a multiplicity of locations (points on a map) and places (clusters of symbols and practices), not a space.

Using space to signify a universal plane, containing locations (sites, positions) and places (values, performances, symbols, associations) is common beyond

(Munich: Beck, 2001); Jay Winter, Sites of Meaning, Sites of Mourning: The Great War in European Cultural History (Cambridge, UK: Cambridge University Press, 1995).

19. Krisztina Robert, 'Constructions of 'Home,' 'Front,' and Women's Military Employment in First World War Britain: A Spatial Interpretation,” History and Theory 52, no. 3 (2013), 316-343.

20. Tim Cresswell, Place: A Short Introduction (Oxford: Oxford University Press, 2004), 5. See also footnote 8 .

21. Paul Gilroy, The Black Atlantic: Modernity and Double Consciousness (London: Verso, 1993).

22. Jürgen Habermas, The Structural Transformation of the Public Sphere: An Enquiry into a Category of Bourgeois Society (Cambridge, UK: Polity, 1989). 
geography, too. A universal plane of interconnected points is what Foucault calls "heterotopia," although he uses the words "space" and "place" themselves so interchangeably that it is hard to be sure. ${ }^{23}$ The use of "space" as an otherwise neutral plane on which locations are distributed is explained perhaps most usefully and accessibly by Anthony Giddens (borrowing from Hägerstrand). $\mathrm{He}$ characterizes space as a void on which the routines and performances of everyday life in modernity are separated, and coordinated with time. ${ }^{24}$ "Space," for Giddens and Foucault, functions largely as a blank canvas (or taxonomic continuum) onto which different places are painted, but in using the word "space," rather than, say, "network of sites," clarity about physical space is once again crowded out by denying it a language - or at least, by so freely using the word "space" that it makes it hard to know what it might refer to. A clearer engagement with the theoretical underpinnings of this material network or "plane of locations" would be a potent way for historians to engage with geographers and anthropologists. Such an emphasis on the distribution and interconnectedness of locations is an assumed underpinning of some of the practices of world and economic history. ${ }^{25}$ However, it still would not solve the problem of space as I have defined it, because it strips space of its particularity, and makes it an empty organizing principle-much in the way that chronology for historians does not show anything in and of itself, but it is essential in understanding the temporal relationships of things. Chronology for historians is a sorting tool, not an explaining tool; space, conceived of as this formless, universal continuum, functions similarly. If space has a status and function similar to chronology (merely a cataloguing or ordering device), it is not worth the intellectual fuss that has been made of it.

\section{THE VALUE OF PLACE, THE VALUE OF LOCATION}

These overlaps and interchangeabilities of space and place in scholarly writing do not imply that place, in the sense that I mean it (the practices, values, symbols, and meanings associated with a location, real or imaginary), is irrelevant or marginal to historical explanation-quite the reverse. Historians who have attended to place have generally acknowledged in their actions, if not their words, the arguments that have underpinned a powerful trend in geography, archaeology, and anthropology over the last thirty years. Although most geographers use "place" to mean "location," they tend also to mean the values, symbols, performances, habits, and meanings associated with that location too. As geographer Tim Cresswell demonstrates clearly in his work, there is a consensus about the performative and cultural aspects of place among geographers: "[T]he majority of writing about place focuses on the realm of meaning and experience. Place is

23. Michel Foucault, "Of Other Spaces,” Diacritics 16 (1986), 22-27.

24. Anthony Giddens, The Constitution of Society: An Outline of a Theory of Structuration (Cambridge, UK: Polity, 1984), 110-158.

25. For example, Kevin O'Rourke and Geoffrey Williamson, Globalization and History: The Evolution of a Nineteenth-Century Atlantic Economy (Cambridge, MA, and London: MIT Press, 1999); Neil Smith, Roosevelt's Geographer and the Prelude to Globalization (Berkeley and London: University of California Press, 2003). This is a burgeoning field. 
how we make the world meaningful and the way we experience the world. Place, at a basic level, is space invested with meaning. . .."26

Drawing on a phenomenological philosophical tradition reaching back through Merleau-Ponty to Heidegger, Husserl, Kant, and beyond, "place" has come to be seen by many scholars as a structuring precondition of human consciousness and being-in-the-world. ${ }^{27}$ Phenomenological approaches reason that to be conscious is to be conscious of something other than the consciousness-forming organ, and that the first thing of which a human is conscious is its environment: that is to say, the not-self. This approach emphasizes that being and consciousness implicitly mean being somewhere, and being conscious of being somewhere, simultaneously. In short, "to be" is "to be in place" (say, in a safe place) and "to be in space" (say, in a cot) and "to be at a location" (say, at grandma's house), and therefore any account of being (or experience or memory) without environment would be trivial. Historians interested in place (as so many are, myself included) might wish to attend to these philosophical niceties, because exploring and presenting the theoretical underpinnings of a "platial" approach would make the very many histories that happen either nowhere or everywhere (for example, in "Germany," as if this were a phenomenological environment that might produce a human consciousness) harder to justify, as well as opening up room for the genuinely spatial, by illuminating the distinctive features of the platial.

Urban cultural historians have been particularly effective at capturing the "emplaced" natures of their subjects, albeit usually without much platially oriented theoretical underpinning. But they have also unwittingly engaged with another key concern of some geographers: the ways that handling multiple locations offers a method to highlight plural simultaneities, rather than flattening the diversity of human experience into one, coherent "moment," with all the violence to complexity that that involves. ${ }^{28}$ Urban cultural historians' usage of plural sites to construct parallel narratives responds, albeit usually unconsciously, to

26. Cresswell, Place, 12. Another readable introduction is Hazel Easthorpe, "A Place Called Home," Housing, Theory and Society 3 (2004), 128-138.

27. Some influential scholars who have surveyed and contributed to this trend are Tim Ingold, The Perception of the Environment: Essays in Livelihood, Dwelling and Skill (London: Routledge, 2000) esp. 157-171; Yi-Fu Tuan, Topophilia: A Study of Environmental Perception, Attitudes, and Values (New York: Prentice Hall, 1974); Tuan, Space and Place: The Perspective of Experience (London: Edward Arnold, 1977); Edward Relph, Place and Placelessness (London: Pion, 1976); Marc Augé, Non-Places: An Introduction to an Anthropology of Supermodernity [1992] (London: Verso, 1995); Daniel Miller, Stuff (Cambridge, UK: Polity, 2010); Miller, The Comfort of Things (Cambridge, UK: Polity, 2008); Michel de Certeau, The Practice of Everyday Life (Berkeley and London: University of California Press, 1988), 117-118; Edward Casey, The Fate of Place: A Philosophical History (Berkeley and London: University of California Press, 1997), 202-285; Samuel Todes, Body and World (Cambridge, MA, and London: MIT Press, 2001); Philip Ethington, "Placing the Past: Groundwork for a Spatial Theory of History," Rethinking History 4 (2007), 465-493.

28. See, for example, Bernard Rulof, "The Affair of the Plan de l'Olivier: Sense of Place and Popular Politics in Nineteenth-Century France," Cultural and Social History 3 (2009), 323-344; Wolfgang Maderthaner and Lutz Musner, Die Anarchie der Vorstadt: Das andere Wien um 1900 (Frankfurt: Campus, 1999); Pamela Swett, Neighbors and Enemies: The Culture of Radicalism in Berlin, 1929-1933 (Cambridge, UK: Cambridge University Press, 2004); Anthony McElligott, Contested City: Municipal Politics and the Rise of Nazism in Altona, 1917-1937 (Ann Arbor: University of Michigan Press, 1998); Frank Mort, Capital Affairs: The Making of the Permissive Society (New Haven and London: Yale University Press, 2010). 
some of the most potent arguments of the highly influential geographer Doreen Massey. She argues that by viewing the world as a dynamic simultaneity of multiple locations in which people perform their interactions, one can attain the overthrow of the tyranny of teleological Eurocentric models of development, or bourgeois models of progress, that can prevail in the social sciences (she has her sights set more on economics, anthropology, sociology, and geography than on history here). In this historical model (derived from nineteenth-century ideas of progress, or Marxian notions of historical change, or economic ideas of development), the people of Rwanda, or the housing project at the end of the road, are like me-just not yet. Real difference or diversity is violently denied by situating it in a developmental, historical, teleological model. For Massey, engaging with a pluralism of locations is a way of overcoming the "prison-house of synchrony," and opening up a world of plural, dynamic simultaneity to reach the conclusion that difference exists and we do not need to correct for it, but rather, embrace it. ${ }^{29}$ Her approach to plural locations and sites is one that historians like me would profit from exploring, and one that many historians would find it easy to integrate into their work - and many have done so, though without engaging closely with positions like Massey's. But although her work is entitled For Space, space again appears here as a meaningless void to coordinate the relationships of particular sites. A more accurate descriptive title would be For Location (or, better, For Locations). This is the way that Amanda Flather, in this issue, complicates the historical arguments about early modern gender: she takes a plurality of locations in order to develop a picture that embraces the complexity in order to shift focus from "a woman's place" (a cultural argument about separate spheres) to "a woman's locations," a geographical argument about how site plurality can demolish academic conventions. ${ }^{30}$

This still leaves historians (and other scholars) with the tricky matter of matter. Although historians may benefit from theorizing the platial aspects of their work, they have already been reasonably skillful at explaining what people thought and did, inasmuch as they wrote it down. But we have, as a profession, been weaker at looking at other forms of evidence. I have attempted it in my own work, arguing, for example, that the physical layout of kitchens was instrumental in forcing certain family structures of everyday life onto women's lives in Weimar Germany, but I resorted to a relatively crass, deductive "naïve empiricism" to do so. ${ }^{31}$ To devise a more complex theory of action will be tricky, and fraught with difficulties - as Matthew Johnson highlights in this volume. ${ }^{32}$ In one of the most refreshing and insightful pieces of methodological work in this field that I have read, architectural historian William Whyte has critiqued historians for viewing buildings (which both he and I agree are good examples of spatial interventions in human affairs) as texts to be read in an uncomplicated way, and proposes

29. Massey, For Space, 36-47, 81-104.

30. Amanda Flather, "Space, Place, and Gender: The Sexual and Spatial Division of Labor in the Early Modern Household," History and Theory 52, no. 3 (2013), 344-360.

31. Jerram, "Kitchen Sink Dramas." The "naïve empirical" approach persisted throughout Streetlife.

32. Matthew H. Johnson, "What Do Medieval Buildings Mean?," History and Theory 52, no. 3 (2013), 380-399. 
very convincing ways of reading them more effectively (and of which historians should take more note). But even for Whyte, the spaces (their matter) exist largely as texts to be (better) interpreted for their meanings, rather than understanding what they do qua spaces. ${ }^{33}$ Johnson echoes this concern in this collection, highlighting the ways that meaning can be meaningless. As historian Ralph Kingston observed in a recent review essay on the spatial turn in history, much of the use that historians have made of space has been, essentially, a replay of the cultural turn, where space has been viewed as a repository of cultural meaning, rather than as a physical "thing" that structures human action. ${ }^{34}$ Effectively, Kingston is challenging the type of assumption that Schwerhoff makes in his comment on the forum, that the "spatial turn' is not about pure facticity and materiality, but about constructivism and symbols." ${ }^{35}$ Kingston concludes that, "[c]entered on the production of spatial ideas, however, our Spatial Turn has obliterated interest in bricks and mortar. Human beings, we argue, interact through space, and only secondarily in space." ${ }^{36}$ When historian Chris Otter searched for the material aspects of urban history, he concluded that the immaterial city had almost entirely displaced the material: "Even Marxist approaches to the city tended to study abstract forces of capital rather than the physical texture of urban space. The cultural turn merely amplified this trend towards immateriality. The material world featured in such analyses, to be sure, but it was relegated to a limited series of roles which left materiality as such largely unexamined." ${ }^{37}$ Otter is part of a trend of scholars across the humanities who are seeking to assert the importance of a materiality in understanding the relationship between matter and humans, and this will be the focus of the next section.

\section{A FRACTURED WHOLE. OR, CAN THE SPACE SPEAK?}

The interchangeability of space and place in much writing is not always accidental. It relates to a deliberate set of elisions, and one that reinforces the incapacity that we have to describe space materially. In doing the research for this article, I was surprised by the almost visceral a priori assertions of holism that I encountered. ${ }^{38}$ Historian Patrick Joyce and social theorist Tony Bennett recently stated that: "The crucial intellectual move . . . is one that turns towards . . . the erasure of familiar conceptual distinctions between the natural and the social, the human and the non-human, and the material and the cultural, divisions that are all in the first place predicated on the immaterial/ material divide." 39 This type of conclusion is widespread. Joyce and Bennett argue that this holism is an important

33. William Whyte, "How do Buildings Mean? Some Issues of Interpretation in the History of Architecture," History and Theory 45, no. 2 (2006), 153-177.

34. Ralph Kingston, "Mind over Matter? History and the Spatial Turn," Cultural and Social History 7 , no. 1 (2010), 111-121.

35. Schwerhoff, "Spaces, Places, and the Historians," 425.

36. Ibid., 114.

37. Chris Otter, "Locating Matter: The Place of Materiality in Urban History," in Material Powers: Cultural Studies, History and the Material Turn, ed. Tony Bennett and Patrick Joyce (London: Routledge, 2010), 38.

38. See, for example, Ingold's almost Damascene account: Perception of the Environment, 3.

39. Introduction to Bennett and Joyce, eds., Material Powers, 4. 
innovation, but in fact, it can be found in thinking about sites for some forty or so years, with the net effect that it is rare that spaces are described in their material forms, distinguished from a range of symbolic functions that relate to them. This holism is vibrant, assertive, and longstanding, and permeates the literature on space and place.

Henri Lefebvre is perhaps the heaviest of heavy hands on the shoulders of discussions about space, and a longstanding apostle of holism. Binary theories, he argued, which posit a res cogitans and a res extensa, imply a "dualism which is entirely mental, and strips everything which makes for living activity from life, thought and society (so, from the physical, mental and social, as from the lived, perceived and conceived)." 40 So he argued that to view these things as dual was itself an illusion produced by the human mind, just as Joyce and Bennett would do forty or so years later. His triangular taxonomy of space stems from this position. It is often quoted, so needs attention, because it models an approach to space devoid of materiality. His model of space comprises:

1. Spatial practice. How people perform in their worlds, for example, "the daily life of a tenant in a government-subsidized high-rise housing project." ${ }^{41}$ It is about people doing things habitually, and with rhythms.

2. Representations of space. This is "conceptualized space, the space of scientists, planners, urbanists, technocratic subdividers, and social engineers." It is a "system of verbal . . . signs." 42

3. Representational spaces. "Space as lived through its associated images and symbols," and it "overlays physical space, making symbolic use of its objects." 43

In short, there is one system of people doing things, and there are two systems of people representing things. But no things! All materiality is elided into the mental (symbolic) or bodily (people doing things) world-explicitly so: "in absolute [physical] space the absolute has no place, for otherwise it would be a 'non-place'." ${ }^{44}$ So while Lefebvre insists there is no division between mind and matter, his taxonomic method proceeds by excluding matter (and using place and space interchangeably, too, it should be noted). That does not look like a successful conquest of the evils of binarism, but a merger that suppresses the capacity to discuss matter. Mind and matter are clearly related; but that cannot mean that only one of them can act.

Leading scholars in many disciplines have concurred in this a priori holism, at least in the attempt to overcome a divide between the internal and the external. ${ }^{45}$ They have "reject[ed] the division between inner and outer worlds - respectively

40. Henri Lefebvre, The Production of Space [1974] (Oxford: Blackwell, 1991), 39.

41. Ibid., 38.

42. Ibid., 38-39.

43. Ibid., 39.

44. Ibid., 35.

45. For example, Ingold, Perception, 3, 191; De Certeau, Practice of Everyday Life, 35-36; Nigel Thrift, Non-Representational Theory: Space, Politics, Affect (London: Routledge, 2008); Pierre Bourdieu, Distinction: A Social Critique of the Judgement of Taste [1979] (London: Routledge, 1984), 466-482. 
of mind and matter, meaning and substance." 46 Some have gone as far as to propose a new category to defeat the problems of thinking about the world in terms of the cultural/social and the material. Edward Soja, a hugely influential geographer, has reinforced this elision, proposing a whole new category of analysis: thirdspace. "Thirdspace, . . ." he expands, "can be described as a creative recombination and extension, one that builds on a Firstspace perspective that is focused on the 'real' material world and a Secondspace perspective that interprets this reality through "imagined' representations of spatiality." 47 The interplay of two measurables (or studiables) has to be profitable to scholarship; but eliding them into a new whole, thirdspace, again marginalizes materiality by denying it a legitimate language. Above all, scholars in geography have borrowed from the phenomenological tradition to unify the "real and imagined" binary in the iterations of the body, revealed in affect (as Johnson begins to do in this issue). ${ }^{48} \mathrm{Just}$ as wealth and poverty are two constituent elements of the same thing, existing on a mutually constitutive scale, and neither makes any sense without the other, few scholars would accept that we should elide the two, and not define who is poor, what poverty is, and what poverty does.

The title to this section cheekily borrows Gayatri Chakravorty Spivak's question, "Can the subaltern speak?," and deliberately so. ${ }^{49}$ In her seminal essay, Spivak proposes that the structure of knowledge with which we (historians and cultural critics, though it is applicable to other disciplines) work emerged in a particular time (the nineteenth century) and location (Europe), which means that the structure of knowledge has been so designed so that one perspective frames all discourse. Words may come from a colonized subject, but they are expressed only in disciplinary or intellectual terms allowed by the colonizing culture. We have reached the same point with words and space. Historians were fixated on words (and, to a lesser degree, numbers) before the cultural turn, but that turn has heightened our focus on them (though it has rather displaced numbers). Maiken Umbach has highlighted that, since the cultural turn, many scholars have delighted in framing textual/verbal evidence as unstable, labile, shifting, and problematic; yet the evidence offered by space or images of space is often seen as just that little bit too unstable, labile, shifting, and problematic..$^{50}$ The same courtesy we extend to words is not extended to space.

A highly problematic aspect of scholarly attempts to use space as evidence of something is the temptation to read from a space knowledge derived from elsewhere-a by-product, perhaps, of the habit of the elision of material and cultural/social. For example, Pierre Bourdieu's early work (foundational to evolv-

46. Ingold, Perception, 191.

47. Edward Soja, Thirdspace: Journeys to Los Angeles and other Real-and-Imagined Places (Oxford: Blackwell, 1996), 6.

48. For example, Thrift, Non-Representational Theory; Peter Kraftl and Peter Adey, "Architecture/ Affect/Inhabitation: Geographies of Being-In Buildings," Annals of the Association of American Geographers 1 (2008), 213-231.

49. Gayatri Chakravorty Spivak, "Can the Subaltern Speak?," in Marxism and the Interpretation of Culture, ed. C. Nelson and L. Grossberg (Basingstoke, UK: Macmillan, 1988), 271-313.

50. Maiken Umbach, German Cities and Bourgeois Modernism, 1890-1924 (Oxford: Oxford University Press, 2009), 12. She actually refers here to images, although images of spaces are surely more tightly representative of the space than a verbal/textual fragment is of an action or a thought. 
ing his theory of habitus, and therefore significant to a study of both place and space as I have defined them) proposed a way of understanding the world that, at first glance, seems profoundly spatial - to do with the disposition of things with regard to one another and humans. In his work on the Kabyle house (which Michel de Certeau rates as "the best that he has written"), Bourdieu argued that the disposition of things in the dwelling did not just symbolize the distinctive features of Kabyle culture, but produced them. ${ }^{51}$ He explained:

It is also in front of the loom wall, facing the door, in full daylight, that the young bride is made to sit, as if to be shown off, like the decorated plates that hang there. When one knows that a baby girl's umbilical cord is buried behind the loom, and that to protect a maiden's virginity, she is made to step through the warp, from the side facing the door to the side next to the loom wall, then the function of magical protection attributed to the loom becomes evident. ${ }^{52}$

Upon further reflection, it becomes clear that no such things could "become evident." No outsider looking at, or being in, a Kabyle house could work out the meanings of the disposition of things, or their effects on the inhabitants, from the things themselves - that is to say, from the space. Bourdieu has generated a large amount of data from other sources, then read those data onto the space, then read them back off the space as if that were whence he derived them. The space itself in this instance cannot speak - acknowledged, in a way, by the concession, "when one knows. ..." The space itself is a room, a door, some plates, and a loom. The rest is Bourdieu, and his knowledge is derived from elsewhere. We may need evidence from elsewhere to achieve understanding - the ways I might relate to a loom opposite a door in 2012 in Manchester would be very different from the ways the Kabyle might relate to it in 1950s Algeria. So I might be foolish to claim to understand the agency of the space without further knowledge. But how we might prevent that subsequent knowledge "infecting," or just obliterating, what we say about the spatial materiality of the loom opposite the door is a problem that remains to be solved-if, indeed, it can be solved. Alternatively, a "naïve materialist" approach to the space might help strip back layers of cultural speculation and social analysis to reveal a "bare" materiality that helps us at least abandon the pretense that we are currently equipped to talk about space itself, and begin reflecting on what sort of tools we might need to do that. It could, in fact, be profoundly liberating to say that this is a loom and a door, not a mechanism for understanding magic, virginity, or the rules by which women should live their lives. It may be liberating to pursue this spatial materialism, in the same way that Marx and Engels pursued an economic materialism.

Johnson, in this issue, shows how such a "naïve empiricism" might help move scholars beyond what things "mean," by situating himself imaginatively and phenomenologically in the spaces he wishes to understand. Although, as he points out, there is no obvious reason why someone today should have the same sensual response to the processes of entering a castle as someone in the fourteenth century. Perhaps space is effectively mute, in which case we might profitably stop

51. De Certeau, Practice of Everyday Life, 50.

52. Pierre Bourdieu, Algeria, 1960: The Disenchantment of the World (Cambridge, UK: Cambridge University Press, 1979), 137. 
turning about it. Others in the social sciences, particularly sociology, have been ready to use a certain sort of spatial "naïve empiricism" to explore complex and dynamic social processes, and have shown that matter in space definitely is not mute. It is determining. In an outstanding work of ethnography, Terence McDonnell sought to understand the ways that meanings and understandings of HIV (or, more accurately, the prevention of HIV) relied on a certain type of reductive, crass materiality by focusing on billboard advertisements in contemporary Accra. People set up stalls in front of, or leaned their stalls against, bus-stop advertisements; some ads faded in the sun, such that they were no longer legible; others became tatty, leading people to scorn the message they contained. As he states, he aimed to move "beyond the observation that all cultural objects have material qualities by systematically investigating how materiality structures interpretive interactions. Depending on the unique instantiation of material qualities inherent in an object and the materiality of the context, an object's materiality may trump symbolic forms of communication such as language. ${ }^{53}$ So materiality acts in its own right and in its own ways, and it can trump meaning and symbolism. Moving materiality further up the causal chain like this is serious stuff. Significantly, though, McDonnell had tools not available to the historian. He could interview passers-by and ask them if they had seen a billboard and what they thought of it. He could see people setting up stalls at bus stops. And he was studying material things that were, in a sense, almost characteristic of the definition of ephemerality: advertising posters. Historians cannot pose questions or observe people's actions in real-time - though they may interpret images or find fragments of text that offer clues. The existing scholarship on things offers starting points, but in this scholarship, the materiality of things is often quite interstitial, in which the thing serves as a mediator between two people, or transports values or emotions around, rather than acting in its own right as a form of "second nature." ${ }^{54}$ In the absence of descriptions of how spaces were used in the past, either spaces themselves must be brought to speak more clearly, or their silence should be respected.

As I will emphasize later, however, space is more durable, more persistent, more like a "second nature" than simply a screen onto which meaning can be projected. Even after many hundreds of years, Johnson's study of Bodiam in this collection is able to frame how certain material dispositions can force, enable, delimit, and prevent. How, then, might spaces be brought to speak? Central to resolving our capacity to tackle space will be a fair amount of intellectual work and debate about materiality. In much work on materiality (not just in history), the materials in question often (though not always) possess a certain sort of ephemerality: coffee, guns, snippets of hair, love spoons, and such like can possess dynamic and multiple lives. They can even sometimes (in the tradition of science and technology studies, of which more later) "configure the user" in

53. Terrence McDonnell, "Cultural Objects: Materiality, Urban Space, and the Interpretation of Aids Campaigns in Accra, Ghana," American Journal of Sociology 6 (2010), 1805.

54. Arjun Appadurai, "Materiality in the Future of Anthropology," in Commodification: Things, Agency and Identities, ed. Wim van Binsbergen and Peter Geschiere (Münster: Lit, 2005), 55-62; Miller, Stuff; Frank Trentmann, "Materiality in the Future of History: Things, Practices and Politics," Journal of British Studies 2 (2009), 283-307. 
interesting ways. The objects that are frequently discussed in histories of material culture are often transitory, both in the way that they often degrade or decay or break up, and in the sense that humans interacting with them can exercise a high degree of agency over them, so they can be ignored. ${ }^{55}$ I might wear a wedding ring, and it may have a function: it keeps jewelers in business, it displays my wealth, it advertises my sexuality (though that function may be fading), it deters unwanted advances, it shows I am married with all the social consequences that can have (say, in getting a job), it might cement a link with my son, or carry the memories of a husband when worn on chain around the neck. But I can take it off. I can give it away. I can hide it for a night. Space, on the other hand, is staggeringly obdurate. ${ }^{56}$ It is breathtakingly hard to produce a space on any sort of scale larger than a human being, whether it be Bodiam Castle, a kitchen, a housing project, a house, a shack in a favela, a shopping mall, a city, or a concentration camp, and, once produced, it is breathtakingly hard to change it. Changing space usually (though not invariably) requires a level of money, power, skill, relationships, debate, consensus-forming (or violence), and sheer physical brutality that does not characterize changes to the usual objects discussed in the literature on material culture.

The tradition of environmental history offers suggestions for understanding this more obdurate notion of space. Environmental history has been widely accepted by the historical profession following Braudel's model-usually taught to all undergraduates in historiography courses, but then left to languish thereafter-and is undergoing a renaissance. More recently, as a sub-discipline, its impact has been frustratingly limited. Perhaps this is because environmental history has tended, to date, to model its historical narrative around the relationship between humans and a "natural" other. However, this is beginning to change: Martin Melosi has suggested that we start to view manmade environments, or man-influenced environments (which is to say, most environments in which humans find themselves), as a form of what he calls "second nature": effectively, the "second nature" is the environment that one finds oneself in, if one did not create it but someone else did. ${ }^{57}$ Thus, Melosi suggests, a street or a housing project should be given the same level of environmental "authority" as a mountain range, ocean, or river, in the sense that streets or housing projects are the environments to which the people in them (and outside them) must adapt themselves, with little in the way of choice. We may inscribe other uses onto these "environmental facts" than the ones that they at first suggest, but unless we are very rich, powerful, and skilled, we are unlikely to be able to change them spatially very much (although we might more readily change more ephemeral

55. See the types of objects that dominated at a recent conference at the Institute of Historical Research in London: https://historyspot.org.uk/podcasts/gerald-aylmer-seminar-2013-why-materialculture (accessed August 16, 2013).

56. On the "obduracy" of spaces, see Anique Hommels, "Studying Obduracy in the City: Toward a Productive Fusion between Technology Studies and Urban Studies," Science, Technology, Human Values 3 (2005), 323-351; Jane Jacobs, Stephen Cairns, and Ignaz Strebel, ““A Tall Storey . . , but a Fact Just the Same': The Red Road High-rise as a Black Box," Urban Studies 3 (2007), 609-629.

57. Martin Melosi, "Humans, Cities and Nature: How do Cities Fit in the Material World?,"Journal of Urban History 3 (2010), 3-21. 
features, like color).$^{58}$ Melosi posits a material world that is historicizable in its subsequent interventions in human affairs as a form of "fact" that compels certain types of response. The obduracy and scale of spatial materiality, and the way it circumscribes (but does not eradicate) the agency of the people in a space, are two of the ways it is different from the more conventional focus on materiality in historical writing.

Many of the difficulties of materiality point the scholar back to a particularly fertile area of its discussion: science and technology studies (STS), and it is on this field that I wish to conclude. Bruno Latour's model of the network of actors, some human, some not, is foundational ("actor-network theory"). Science and technology studies has been significant in advancing theories or models of agency that transcend conventional models based on nature, social structures, and cultures of meaning or discursive practice. In one of his most accessible and stimulating essays on matter, Latour proposes something of a "democratization" of who and what can act, suggesting we look for the "missing masses" of the world, but only inasmuch as we accept a model of a network or group as something profoundly unstable and contingent. ${ }^{59}$ But if one is to posit a world of networks, then however labile and contingent the network might be, it behooves us to attend to the points between which we see human experience taking place in order to work up to the network as a whole. That means accepting a certain amount of "naïve materialism," and mind/matter binarism, if only as a heuristic device to get the ball rolling about the parameters of the relationship we are investigating.

Yet the recent willingness to think about what things do is not without its problems, partly because of the "culture of holism" discussed above, and partly because as scholars we struggle to explain influence while distancing ourselves from determinism. Latour's insistence that objects can author actions is promising, but with the tendency that agency and structure be collapsed into "hybrid" forms, all those things that are "culture and nature," he is once again overcoming the distinction between the world out there and the world in here by collapsing it. Once collapsed like this, its existence must then be re-established, on what must be, in my view, far less useful foundations (although they may be intellectually purer). For example, he argues:

Take, for instance, the case of the platinum kilogram maintained by the International Bureau of Weights and Measures (Bureau International des Poids et Mésures) in a deep vault inside the Breteuil Pavillon at the Sèvres Park outside of Paris. Is it a convention? Yes. Is it a material object? Yes. Is it an international institution? Once more, yes. Does it represent the head of a metrological chain, the ideal model to which all other inferior copies are compared in a solemn ceremony once every two years? Again, yes. There is no doubt that it is a hybrid. ${ }^{60}$

58. Anthropologist of materiality Daniel Miller highlights this in many of his discussions, but a particularly apposite one in this context is "Appropriating the State on the Council Estate," Man 2 (1988), 353-372.

59. Bruno Latour, "Where are the Missing Masses? The Sociology of a Few Mundane Artifacts," in Shaping Technology/Building Society: Studies in Sociotechnical Change, ed. Wiebe Bijker and John Law (Cambridge, MA: MIT Press, 1992), 225-258.

60. Bruno Latour, Reassembling the Social: An Introduction to Actor-Network-Theory (Oxford: Oxford University Press, 2007), 228. 
It seems that no sooner does one touch on the material than one diverts to its immateriality, hybridity, and holism. I do not wish to argue that the immaterial lives of things do not matter, only that in our unremitting emphasis on them since the cultural turn, we preclude a vocabulary-let alone a theory - to talk about materiality an sich. And this has profound implications for the idea of material space as McDonnell conceives it: as something that acts. There are many scholars in STS who offer us pointers; I will focus on just one. It is not a complete solution, but one that seems particularly useful to historians.

Thomas Gieryn is a sociologist who is interested in how space is used in science, both in its physical and platial qualities. His writing has influenced this essay profoundly, because it proposes a model that is quite historically "available." In his article "What Buildings Do," he begins to expand on the materiality of buildings. ${ }^{61}$ Gieryn argues that approaches that focus on space, which is largely or solely conceived through human action or thoughts or symbols, tends to subsume understandings of matter into a "real-and-imaginary" whole that ultimately cannot ascribe agency to a building. This is because (and this is my gloss on his writings) such approaches cannot get beyond the basic cultural prejudice against the material and toward the mental (a cultural prejudice that pervades Western thought, all the way back to Plato's hierarchy of knowledge developed in the Sun, Divided Line, and Cave in the Republic). Gieryn is very alive to the interplay of cultural/social place, human actions, and material space. ${ }^{62}$ Gieryn's way out of this is one that is useful to historians, partly because of its micro-periodizations.

In exploring the life of a building (which I take to be one of the most archetypal and conspicuous uses of space to intervene in human affairs), Gieryn proposes a tipping point when infinite malleability takes on a solid form that is not immutable, but very hard to change - one might add, just as class and gender and sexuality are always mutable, but rarely mutate in an easy or convenient way to people possessing them. In effect, buildings become a "second nature." He explains:

Some designs get built. What once was a malleable plan - an unsettled thing pushed in different directions by competing interests during negotiation and compromise-now attains stability. Many possibilities become one actuality. Constructivists use the term "closure" to describe the transition of plastic plans into obdurate machines or buildings. The resulting "black box" secures a material artifact and those social relations now built into its design. Once sealed shut, machines are capable of steering social action in ways not always meaningfully apprehended by actors or necessarily congruent with their interests or values. ${ }^{63}$

As historians, we have a potent set of chronological phases here for scholarly spatial practice. First, we can attend to all the cultural, symbolic, and performative processes by which certain spaces come to be configured in the way that they are, used in the way that they are, valued in the way that they are-so, place as I have defined it. But then we reach a problem, and one that will require substantial work for historians to overcome: closure. Thereafter, it becomes remarkably

61. Thomas Gieryn, "What Buildings Do," Theory and Society 34 (2002), 35-74.

62. Ibid., 43. On place, see: Thomas Gieryn, "City as Truth-Spot: Laboratories and Field Sites in Urban Studies," Social Studies in Science 1 (2006), 5-38; Gieryn, "A Space for Place in Sociology." 63. Gieryn, "What Buildings Do," 43. 
difficult (though not impossible) to adapt the "thing," especially if it possesses the obduracy of space, and thereafter the material artifact in all its complexity "configures the user," in the language of science studies. There is a historical tipping point at which these spaces (buildings) take shape and thereupon become a material cause, producing effects beyond their symbolic functions. Interpreting this effect must be central to any meaningful "spatial turn," if we are to go beyond the endless pursuit of meanings. If we accept, as McDonnell and Gieryn do, that space acts, we are left with a set of urgent methodological questions because we cannot conduct the ethnographic surveys that they have been able to do.

Historians already use place and location to great effect. If we are content to view a space (not all space, $a$ space) like a building (or a motorway, or a street) as a material artifact "capable of steering social action in ways not always meaningfully apprehended by actors," then we need to start the long, slow process of asking (and theorizing):

1. How might that steering happen? What is doing what to what-and whom? What is the mechanism of action, the line of reasoning that runs from spatial cause $\rightarrow$ human effect? It is unclear that even professionals in the field (such as architects, builders, or planners) can make consistently accurate predictions about what a space will do-or even if they are interested in doing so.

2. How might historians meaningfully apprehend it, if users cannot?

3. What evidence might be discoverable and admissible to address the problem? What should the relationship be between the spatial evidence and the verbal? Can the space speak, or must the historian speak for it? Is an image of the original space superior or inferior to the historian phenomenologically interpreting a surviving space, however degraded?

Pursuing the tantalizing offering of a world where "things" do would mean abandoning, even only briefly or heuristically, our attempts to erase the nature/ nurture dichotomy and asking what new types of evidence are out there and how we might handle them.

\section{CONCLUSIONS}

Most scholarly writing does not attend at all to the environments in which humans exist. Soja's critique of economists could apply equally to historians: they write as if their subject were "packed solidly on the head of a pin." ${ }^{64}$ Scholars who do attend to environments mostly emphasize the values, beliefs, actions, and performances associated with those environments, in the character of "place." Yet the profitable attention to place (when it has been offered) has a) been undertheorized; b) functioned to make it harder to talk about space, because the word "space" has also been used interchangeably with place to refer to values, symbols, beliefs, actions, and performances; and c) because the word "place" has also been used to refer to locations. This frequent silence about the world that humans

64. Edward Soja, Post-modern Geographies: The Reassertion of Space in Critical Social Theory (London: Verso, 1989), 32. 
are in (rather than the perceptions that humans have of it, or the things they do in it) is not a problem unique to historians, but it does degrade the capacity to deal with the material world almost to zero, by crowding out a possible vocabulary for it. Without a vocabulary for the material environment that is understood to mean "the material environment," and not "just about anything about the environment, or anyone's beliefs about the environment, or anyone's actions in an environment that can be described," the status of the obdurate matter of "a space" will always be uncertain, if not outright excluded. Quite possibly, this does not matter. But if it does not matter, we should come out and say so, and theorize that position too. If colleagues think that "where" is unconnected to "what" and "why" and "how," then this should be stated and proven.

In some ways, this attention to matter, and producing truth-claims from matter, is almost habitual for historians. Historians spend huge amounts of time looking at pieces of matter, all products of invented technologies (paper-making, writing, printing, and so on). And from that matter, they deduce all sorts of causes, all sorts of effects. Whole states rise and fall on the basis of these chits of paper. We need, though, to ask about things - but things not just as transactional objects, or containers of emotions and identities, be they invested with ever-so-much meaning. Spaces go beyond conventional uses of materiality because they have intractability, an obduracy that leaves us having to deal with them as a sort of "second nature," so to view a space as a thing will require further work, thought, and arbitration.

This depends, of course, on whether there is any value perceived in such a project, or if we are content to analyze the world through nowhere/everywhere categories like the economy or class. If we see value in it, we need to define its component features more carefully. We can start by fleshing out theoretically the more consensual areas of historical investigation, by asserting more confidently the importance of place and emplacement to all human inquiry. We can then proceed to analyze the role of location, distribution, scale, distance, and connectivity, as historians of globalization have done. Finally, we need to decide if the matter of space matters. If it does, we need to explain how and why. If we are seriously to engage with space, there are some obstacles to overcome. We need to accept that practice, iteration, and embodiment are important, but they are all actions. They are people doing things, not things doing things. We need to accept that holism, at some level, presumes separate things that need to be made whole. And we need to accept that networks exist between things, and that therefore defining and studying the things in a network are useful. If there is no value in space, then we should conclude forthrightly that space is a useless category of historical analysis. I do not think that it is, but I hope that a little bit of taxonomic clarity can stimulate thinking about how to proceed, and both moderate the claims made for a genuinely "spatial" turn as well as inspire clearer assertions of the ways that space acts in historical scholarship. 